\title{
Strengthening Rural Extension Services to Facilitate Community towards Sustainable Development Goals in Three Districts in Indonesia
}

\author{
Siti Amanah ${ }^{1}$ dan Anna Fatchiya ${ }^{1}$ \\ ${ }^{1}$ Department of Communication and Community Development Sciences, Faculty of Human Ecology, \\ Bogor Agricultural University (IPB), Dramaga Campus, Bogor, West Java, Indonesia 16680
}

\begin{abstract}
Rural areas in Indonesia vary in terms of socio-economics and cultural background, the landscape, physical climate, the resources, and the accessibility to extension services. Rural extension services play an important role in facilitating community development from on-farm to off farm activities. Rural extension systems have to address the increased demand for the services and to find innovative approaches and strategies to facilitate community in the era of globalization. The paper aims to analyse the current status of rural extension systems in Indonesia, to analyse the role of stakeholders involved in extension systems, and to formulate plan and actions to strengthen rural extension systems. Assessment of rural extension systems was conducted by using a logical framework analysis models involving representatives from rural community groups and resource persons. Stakeholder dialogues and group discussions were conducted to gather information and to discuss the issues on rural extension. Data were analysed using stakeholders analysis to formulate strategy to strengthen rural extension systems. The results indicate that rural areas have shown changes in terms of socio-ecological aspects, land-uses, sources of income, and availability of resources. The changes are due to population increases that result in the need for more food, housing, education, jobs, and other public facilities. Community groups run small enterprise in rural areas for income generating activities. Engaging community and related stakeholders in the systems has positive effects for successful rural extension services. Stakeholder analysis showed that better collaborative extension services from service providers is needed to facilitate community. In terms of sustainable development goals, rural extension systems need the issues of food, health, water, gender, poverty and environment to be integrated into the services. Existing supports from local government, business sectors, civil society organizations, and universities are essentials to facilitate transformative changes in communities.
\end{abstract}

Keywords: eliminate poverty, extension systems, stakeholder dialogues

\section{Introduction}

Rural community in Indonesia depend on agriculture as source of income, in terms of on farm or off-farm agriculture. Agricultural extension is just one aspect of rural extension (Rivera; Qamar, 2003). The tasks associated with "rural extension" are not only agriculture, but also about non-agricultural areas needing attention including small-medium enterprise development, literacy education, family planning, nutrition, health and related aspects. Extension can be provided by the extension officers, farmers, universities, private sectors, and mass media organizations (Garforth; Lawrence, 1997). Indonesia Law Number 16/2006 about Agricultural, Fisheries, and Forestry Extension Systems states that providers for extension services in Indonesia are the government, community leaders, and private sector. Considering facilitating rural community, extension services can be provided by either a separate or integrated extension staff.

The shift in emphasis of extension services are apparent in the way its implemented, from agricultural production, to facilitate farmers organize themselves, and to link farmers to markets (Swanson 2006; Shepherd, 2007). Rural extension services play important role in transformative changes, including to alleviate poverty. The number of people living under poverty in September 2016 were 27.76 million, and 62.24 percent of them lived in rural areas (Central Bureau of Statistics, 2017). The average size of land holding of the farmers is less than 1 hectare (Central Bureau of Statistics, 2013). Twenty six millions small farmers hold 0.89 hectare per household, whilst 14.25 million farmers hold 0.5 hectare per household. Lacking land holding results in limited access to financial support for farm development to run the business, lack of access to information technology and innovations (Herianto et al., 2010) and find difficulties to support the familiy needs. Income generating activities through providing empployment is needed to alleviate poverty. It is the fact that agriculture remains predominant source of employment in Indonesia; it absorbed 35 percent of labour force (Hermanto; Hardono, 2015). 
At the end of 2016, from 74910 villages in Indonesia (Ministry of Domestic Affairs, 2015), 95 percent or 71479 villages needed to be facilitated by extension services (Ministry of Agriculture, 2016). Due to the limited number of extension workers compare to the needs from the fields, cooperative extension works are needed. In 2016, there were 47412 agriculture extension workers (Ministry of Agriculture, 2016); 3145 fisheries extension workers (Ministry of Fisheries and Marine Affairs, 2016); and 3892 forestry extension workers (Ministry of Environment and Forestry, 2016). Volunteer farmers, private sectors, and community led extension services from other organizations including research centers and universities need to co-operate in rural extension systems. The challenges to alleviate poverty require a holistic and transdisciplinary approaches.

Rural areas in Indonesia vary according to physical environment, socio-culture, and economics. Rural extension services should consider that people from different rural areas have specific belief system, values, issues, needs, experiences, and interests. Lack of coordination between stakeholders, unappropriate services with community needs, and lack interests to invest in agricultural and rural extension are among the issues found in dealing with holistic and multistakeholders approaches. On the other hands, increase urbanization increased due to lack of land provision, lack of employment, failure in harvesting the products related to the effect of climate changes, and rapid changes in extension organization affect the operationalization of rural extension systems.

To respond to the call of sustainability, some issues in rural areas need to recover. This paper aims to analyse the current status of rural extension systems and the role of stakeholders in rural extension systems. Results of analysis is used to to formulate plans and actions to strengthen rural extension systems in the context of sustainability.

\section{Rural Extension Systems and Sustainable Perspectives}

Extension-education can be seen as an approach to enable transformative changes to occur through facilitating people to be able to help themselves (Slamet, 2003), communication of innovation (Leewis, 2004), facilitating learning for a

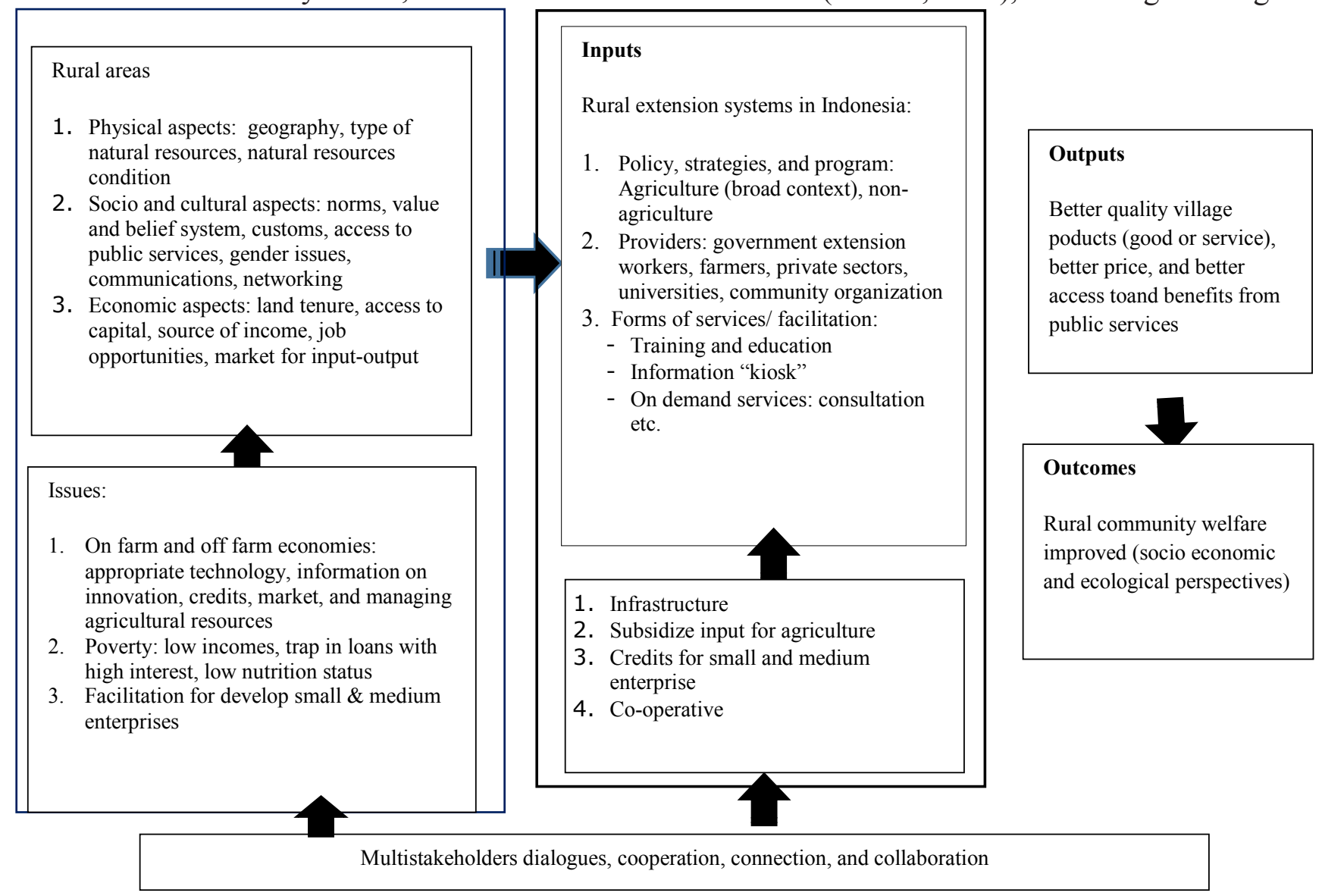

Figure 1. Conceptual Framework "Strengthen Rural Extension Systems": the Case of Rural Indonesia 
better future (Amanah 2007), and as advisory services related to innovation systems (Swanson; Rajalahti, 2010). Australasia-Pacific Extension Network (APEN) defines extension as follows: "about working with people in a community to facilitate change in an environment that has social, economic and technical complexity. This is achieved by helping people gain the knowledge and confidence so they want to change and providing support to ensure it is implemented effectively. through working with the peple to o facilitate change in an environment that has social, economic and technical complexity" (http://www. apen.org.au/what-is-extension).

Rural extension systems is an integrative approach to facilitate the changes for people in the way they manage the resources, develop co-operation with others for social relations, environmental concerns as well as to generate income from activities. For nonagricultural aspects, extension services in rural areas can be integrated with health services, parenting education, home economics consultation, youth organization development, community nutrition, family planning and community library. In viewing rural extension systems as interconnectivity of sub systems to meet community demand for facilitation and that the system "does not simply mean to logical cause and effect, nor problems and solution, systemic approach reflects the connectivity and interrelatedness of whole within whose, systemic analysis is always recursive" (Bawden, 2005).

In the last three decades, a number of model for extension systems have been operated around the world. At least there are five models for extension systems (Amanah, 2008; Amanah, 2013): (i) linear model that characterized by top-down approach and extension services are too focus on production. The farmers are passive and treat as the recipients; (ii) Communication, education, and information (CEI) approach. At this time, the use communication media (mass media) was very intensive to influence mass in decision making process to adopt innovation, (iii) Mass Approach during green revolution era (1960-s to 1980-s). The Training \& Visits System was introduced and developed in these two decades. The Training and Visits ( $\mathrm{T} \& \mathrm{~V}$ ) have been modified in terms of providing more facilitation to the needs of farmers following its assessment that $\mathrm{T} \& \mathrm{~V}$ was too focused on administrative matters that prevented extension workers from visiting farmers more based on the needs for resolving issue on farm and off farm. (iv) Triangle relation between research, extension, and community. This model developed in 1980-s with the aim to link and to interrelate among those involved in communication of innovation for transformative changes. The challenges for this model include for example different "language" between research, extension, and community. (v) participatory extension approach has been developed since in 1970-s, however, due to the need to food security through mass approach, in practically, top-down extension model operated in that period with some cases in Indonesia and other developing countries (Pretty, 1995).

In the late 1987, participatory model in extension was developed by engaging farmers as change agents, for example: Farmer Field School (FFS) Program in Indonesia has been successfully implemented as medium for farmers to learn and solve problem together, when the problem persist the farmers consult to appropriate resources or experts. The approach can be viewed as "farmer back to farmer model" that was introduced by Rhoades and Booth (1982) as an alternative to solve issues on farm level.

Rural extension services need to consider the facts that rural areas face the issues of decline quality of soil resources, increase land conversion from forestry and land use change from agriculture to other purposes, food shortage, and responsible agricultural and fisheries practices (as resumed in Figure 1). Qualitative assessment on National Community Empowerment Program in Rural Environment (Kolopaking et al., 2012) shows that status of agroecosystem and natural resources has co-relations with the community initiatives and facilitation from rural environmental extension services. In the context of sustainable development goals (SDGs) that has been launched on September 25th by the United Nation (the UN).

The SDGs aim to end all forms of poverty and call for action by all countries to promote prosperity while protecting the planet. Ending poverty must be done together with strategies that economic growth should be followed by the fulfilment of social needs including education, health, social protection, and job opportunities, while the issues of climate change and environmental protection (adapted from http:// www.un.org/sustainabledevelopment/sustainabledevelopment-goals).

The new sustainable development agenda has a set of 17 goals that can be divided into three groups those are: (i) end poverty that consists of goal 1 to 6 , 
(ii) protect the planet refers to goal 7 to 12 , and (iii) ensure prosperity for all refer to goal 13 to 17 For the case of rural community Indonesia, the SGDs number 1 to 13 seems relevant in this current situations. In the context of rural extension systems, the paper will discuss rural extension systems that have significant impacts to poverty alleviation, support rural food system, and education for all and gender equality in extension.

Figure 1 shows the illustration of rural extension systems in Indonesia in a logical framework. The left two boxes representing rural areas condition and the issues need to be addressed by extension services. The two boxes in the middle is the providers of the services. To increase effectiveness of the services, extension systems require support from and stakeholders involved in the system need to establish cooperation, connection, and collaboration toward SDGs.

This can be done when multi stakeholder dialogues existed, rural people have interest and committed to "grow" further, and appropriate technology or innovation is able to access and to use by the people. At this point, the role of extension workers or volunteer farmers as facilitators and partners for the farmers and their family is needed. In the perspective of extension as learning for sustainability, three basic components should be available (Gabathuler et al., 2011) multi stakeholder dialogues, organizational development, and knowledge management.

\section{Methods}

A logic model was used to analyse rural extension systems that operated in the last 10 years. The model is a picture of program representing theory of action about input (what is invested), process (what is done), and results (what are the outputs or products). Despite its rational perspective, a logic model will assist an assesor about the performa of the program or a system. From the analysis, continous improvement can be done to increase quality (Adapted from Powell, 2001).

Three data gathering techniques were administered to collect data: interviews, group discussions, and stakeholder dialogues. Primary data about agriculture and rural extension services were gathered from interviews with farmers in Bogor $\operatorname{District}(\mathrm{n}=30)$ and Bandung District $(\mathrm{n}=30)$; farmersfishery communities in Tangerang District $(n=30)$. The respondents were representatives of farmer's groups in three districts. The respondents were asked their perceptions to these seven aspects: (i) current status of agricultural resources in rural areas, (ii) type of rural extension services; (iii) involvement of the community and other stakeholders in extension program planning; (iv) the benefits of rural extension for farmers and fishery community; (v) the priorities for rural extension service in the context of sustainable rural livelihood; (vi) extension services monitoring and evaluation; and (vii) the utilisation of evaluation results.

Group discussions were conducted separately between extension workers $(n=10)$ and the farmers/ women farmers $(n=10)$ to enable objective comments expressed by participants of the group discussion. Stakeholders dialogues were held by inviting researchers of extension-education and academicians $(n=10)$; representatives of government agencies managing extension in agriculture $(\mathrm{n}=5)$ and nonagricultural context $(n=5)$, civil society organizations $(n=4)$, and private sectors $(n=1)$.

Guidance questions in group discussions consists of five aspects: (i) assessment to rural extension services and sustainable issues; (ii) priorities for rural extension services; (iii) stakeholders for rural extension services and their roles in providing the ervices; (iv) the challenges of rural extension services that affect effectiveness of the systems; and (v) aspects of rural extension services that urge to be strengthened.

Logic models to analyse rural extension systems has been depicted to Figure 1 in the previous section of this paper. The generic logic model analysis for program performa is: INPUTS - PROCESS - OUTPUTS - OUTCOMES (Powell 2001). The planning process flows from expected outcomes, targetted outputs, and inputs need to invest. On the other hand, evaluation process starts from inputs that have been invested, the outputs achieved, and the benefits. For the purpose of assessing extension systems, data and information gathered were categories according its position as components of logic models.

Stakeholder mapping was used to identify key stakeholders and their roles in the process of development rural extension systems. The role of stakeholders were categorised according to functions and degree of involvement in the extension services. Plan actions to strengthen rural extension system was formulated based on results of logic model analysis and stakeholder analysis. 


\section{Results and Discussion}

\section{Rural Extension Systems in Indonesia}

Agricultural resources, socio-economic activities, type of ecosystem and the needs for rural people to extension services vary. Farmers and women farmers respondents in Bogor District have developed small entreprise in food processing from taro, sweet potato, cassava, nutmeg, mushroom, potato, corn, and baby fish. Rural people in Bandung District mostly depend their livelihood in agricultural resources. Majority of farmers in Pangalengan and Lembang Subdistricts raise cattle to produce dairy products, do ecosystem service through agroforestry for livelihoods, and women farmers in these subdistricts process milk for cake, crackers, and sweets to be sold as souvenirs for visitors. Respondents in Tangerang District managed lowland vegetable crops and rural community in coastal areas of Tangerang Districts depend their livelihood in agriculture and catching fishery. The similarities of rural people in three districts are: majority of them manage small piece of land to be manages (less than 0.5 hectares), not all farmers become members of the groups (farmers group or fishermen/women group), require agricultural innocation for preventing failure in harvesting yields, and fair prices for the products.

As shown in Table 1, major providers of extension services is the government, whilst the farmer to farmer extension services facilitated by farmer leaders is also availabe, but limited service due

Table 1. Profile of Rural Extension Systems according in Indonesia

\begin{tabular}{|c|c|c|}
\hline Aspect & Agriculture & Non Agriculture \\
\hline \multirow[t]{4}{*}{ Providers } & $\begin{array}{l}\text { Government: Ministry of Agriculture, } \\
\text { Agricultural Agency, Minsitry of } \\
\text { Forestry }\end{array}$ & $\begin{array}{l}\text { Ministry of Public Works } \\
\text { Ministry of Health } \\
\text { Ministry for social }\end{array}$ \\
\hline & $\begin{array}{l}\text { Farmers \& Community: Farmers/ } \\
\text { women farmers leaders }\end{array}$ & Village cadre, civil soceity organization \\
\hline & $\begin{array}{l}\text { Private sectors: training on technical } \\
\text { aspects }\end{array}$ & Private sectors: heatlh services \\
\hline & $\begin{array}{l}\text { Universities: outreach and community } \\
\text { services }\end{array}$ & $\begin{array}{l}\text { Universities: various aspects of rural } \\
\text { livelihoods }\end{array}$ \\
\hline Type of rural landscape & $\begin{array}{l}\text { from lowland to highland } \\
\text { (coastal in Tangerang, rice paddy fields } \\
\text { in Bogor, }\end{array}$ & $\begin{array}{l}\text { Transitional from agriculture (primary } \\
\text { production) to providing service }\end{array}$ \\
\hline $\begin{array}{l}\text { Stakeholders involved in } \\
\text { planning and evaluation }\end{array}$ & $\begin{array}{l}\text { Farmers, women farmers, village } \\
\text { leaders, extension workers }\end{array}$ & $\begin{array}{l}\text { Cadre, representative of families, youth, } \\
\text { school children, leaders }\end{array}$ \\
\hline Beneficiaries & $\begin{array}{l}\text { Farmers and family, farmers group, } \\
\text { women farmers }\end{array}$ & $\begin{array}{l}\text { Rural people in general and specific group } \\
\text { of rural depending on the services }\end{array}$ \\
\hline Priorities of services & $\begin{array}{l}\text { Self reliance on foods, stressing of } \\
\text { extension services is in PAJALE (rice, } \\
\text { corn, soybean) and starting in } 2017 \\
\text { added by meat production }\end{array}$ & $\begin{array}{l}\text { Income generating activities, health and } \\
\text { nutrition services, leadership, and youth } \\
\text { program }\end{array}$ \\
\hline Financial & $\begin{array}{l}\text { Government, grant from international } \\
\text { foundation, loan, and co-funding }\end{array}$ & $\begin{array}{l}\text { Government, private sectors, and } \\
\text { international foundation }\end{array}$ \\
\hline Methods & Mixed methods & Mixed methods \\
\hline Outputs & $\begin{array}{l}\text { Tangible outputs: yields of production } \\
\text { Intangible: change in behaviour to } \\
\text { agricultutal input and managing } \\
\text { resources }\end{array}$ & $\begin{array}{l}\text { Tangible outputs: infrastructure (irrigation, } \\
\text { roads, electricity), public health services } \\
\text { buildings } \\
\text { Intangible: better situation }\end{array}$ \\
\hline Outcomes & $\begin{array}{l}\text { Better rural living (socio-economics } \\
\text { and better environment) }\end{array}$ & Health status of rural people improved \\
\hline
\end{tabular}


to financial reason. Extension services provided by private sectors mostly related to marketing products from company, i.e. fertilizers, seeds, machinery, and chemicals.

A number of rural empowerment programs that have been implemented in rural areas of the three districts including national program for community empowerment, credits for women, family planning program, water and sanitation program, internet facilitation, 9 years learning compulsory, ecovillage, family planning program and community nutrition program. Figure 2 shows farmers assessment $(n=90)$ to rural extension systems in Indonesia. According to farmer repondents, rural extension services remain the same in the last ten years in terms of providers, program, and scope of the services.

Considering the issues of poverty in the three locations, 30 percents of respondents have household income below USD 2 per day. This is also consistent to the major issue in rural areas (Table 2) as presented by the farmers in three districts when they asked to rank five major issues in ordered, they put income as the first issue to overcome. To cope with low income issue, rural people find jobs in the village or to the city, such as laundry services, taxibike, taxidriver, street vendor, and other informal jobs (Source: indepth interviews with the respondents June 2017). A household earns additional income from USD 5

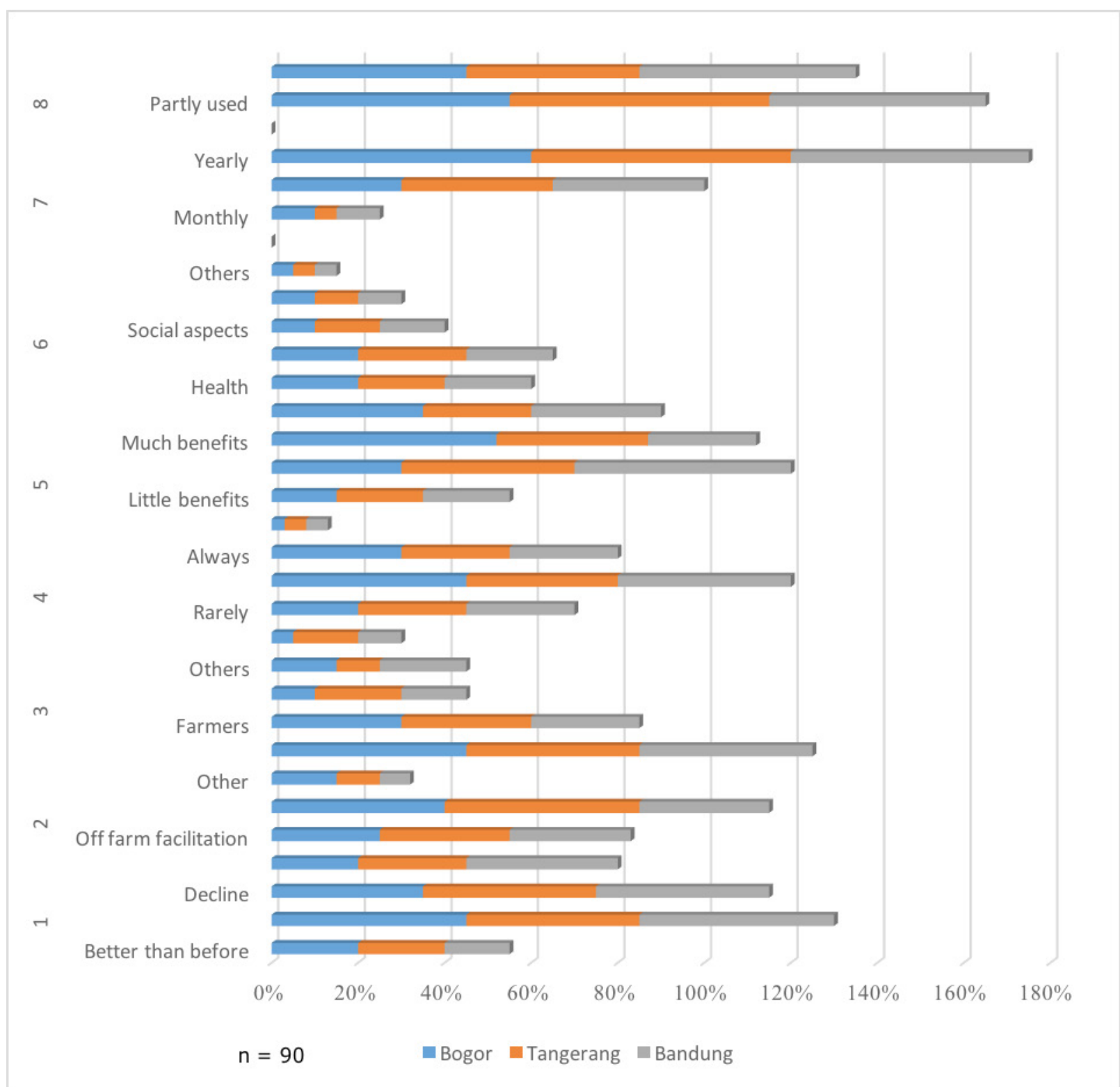

Figure 2. Farmers Perceptual Assessment to Rural Extension Services in Three Districts, 2017

Note: 1. Extension systems,

2 type of rural extension services,

3 providers,
4. involvement in program planning,

5 . benefits of rural extension,

6. services priorities,
7. monitoring \& evaluation, and

8. utilisation of evaluation results. 
Table 3. Major Issues in Rural Areas according to Farmers in the Three Districts

\begin{tabular}{|c|c|c|}
\hline Priority & Issues in rural areas & Activities need to be srengthened further \\
\hline 1 & Lack of income to fulfil household needs & Creating more markets for ag. and rural products \\
\hline 2 & Limited employment for people & More job's opportunities in the villages \\
\hline 3 & $\begin{array}{l}\text { Limited availability of inputs for agriculture } \\
\text { and better infrastructure }\end{array}$ & $\begin{array}{l}\text { Agricultural inputs provided by co-operatives and } \\
\text { infrastructure development (irrigations, roads, and } \\
\text { village barns) }\end{array}$ \\
\hline 4 & $\begin{array}{l}\text { Limited access to education and training as } \\
\text { needed by small farmers }\end{array}$ & $\begin{array}{l}\text { Capacity development program (from government, } \\
\text { business sectors, university, and farmer) }\end{array}$ \\
\hline 5 & $\begin{array}{l}\text { Food shortage and lack of nutritions in rural } \\
\text { areas }\end{array}$ & $\begin{array}{l}\text { - } \text { Farmers need to apply multiple cropping system } \\
\text { - Strengthen rural community capacity in harvest } \\
\text { - Nutrition and community health education; and } \\
\text { health public services }\end{array}$ \\
\hline
\end{tabular}

to USD 12 from other job. Usually, a household in rural areas has to do multiple jobs to have a better income. Work in the city is one choice. More jobs should be provided in rural areas to prevent massive urbanization.

Poverty alleviation programs have been implemented since 1980 s with a number of activities, such as: credits for women, rice distribution to poor people, and 9 years compulsary schooling. Even though the number of poor people has decreased in the last five years, however, the type of poverty has shifted from cultural poverty into more structural poverty, meaning, poverty exist due to structure of socio-economics that people without asset, lack access to credits and other public services.

\section{Role of Stakeholders Involved in Extension Systems}

Group discussions result shows that each stakeholder have specific roles in rural extension systems. Rural extension systems can be viewed as interrelations between element of each subsystem of extension to facilitate transformative changes to occur, in on farm and off farm. Table 4 resumes the results from stakeholders dialogues on extension systems.

Multistakeholders dialogues participants agree that facilitation from extension services has positive correlations to the increase quality of products or services in terms of SDGs. This agreement seems an answer to Davis (2016) questioning about extension contribution to SDGs.

\section{Plan and Actions to Strengthen Rural Extension System}

Twenty two things need to be done from information on Table 4, to strenghten rural extension systems in Indonesia. The 22 things are: 12 aspects to manage inputs, five things to improve the process, three aspects to better handling outputs, and two aspects to expand outcomes from extension services facilitiated by the systems. As extension-education concerns on learning for transformative changes and in the light of SGDs, it is important to review the intended changes according to Leagans (1962):

"Changes in what people know - their knowledge of themselves of their society and of their physical environment, changes in what people can do - their skill, mental and physical, changes in what people think and feel their attitude toward themselves, toward their society and toward their physical environment, and changes in what people actually do their actions related to factors determining their own welfare" (Leagans 1962)

The government needs to ensure whether rural extension systems have addressed the scope of extension services needed by the community. Rural extension services are expected to reformulate approach and methods to assist or to facilitate farmers and community to solve the issues in rural areas including low household income, lack of jobs, limited access to inputs, lack of infrastructure availability, and other issues related to education and training, food and nutrition issues. The plan can be divided into three phases: short, medium, and long terms. In the short 
Table 4. Results of Stakeholders Analysis Based on Logic Aspects in Rural Extension Systems

\begin{tabular}{|c|c|}
\hline Subsystem & Stakeholders \\
\hline
\end{tabular}

1 Inputs

1.2 farmer and local communities

1.3 private company such as seed and chemicals companies:

1.4 university organizations that provided extension services

2 Process

3 Outputs

2.1 manager of the program

2.2 rural community

2.3 private sectors

2.4 extension providers

3.1 farmers

3.2 buyers

3.3 the government

$4 \quad$ Outcomes
4.1 the farmers
and family

4.2 wider community
1.1.1 strategic planning and policies for the services need more support from local government budgetting

1.1.2 some regulation and policies have changed the extension pratices due to organizational changes

1.2.1 have different needs and expectations

1.2.2 work in a decline agricultural resources

\subsection{3 lack of assets}

1.2.4 weak bargaining position in marketing the products (needs fair prices for the products)

1.2.5 need facilitation in adaptation and mitigation technology to respond to environmental issues

1.3.1 orientation is profit from the business

1.3.2 have skills and competent agents

\subsection{3 wide network globally}

1.4.1 have diverse programs which relevant to rural issues

1.4.2 the students have only two month elective program for community service/outreach in certain rural areas ( 2 credits) due to constraint of time and budget

2.1 the program is more focus to achieve the targets: productions, number of bridges builts

2.2 not all rural people participate due to unmatched schedule, not interested, and other reasons 2.3 limited supports to rural extension systems

2.4 evaluation have not been done as a continual process

3.1 weaknesses in handling and processing the product

\section{2 expect appropriate prices}

3.3 the government should control the prices and take a decision to manage the situation e.g. fluctuated hot chilli prices that occurred in in Indonesia from the end of last year to April 2017

4.1 rural people need to better manage the products and service for better quality of life

4.2 forum for multi stakeholders dialogues have only existed insidentillay to discuss plan and action for improvement in rural areas
1.1.1 establish forum for syncronization and better coordination between central and local government

1.1.2 allow modification in the fields for enabling extension workers and other providers to work together rather to work separately

1.2.1 extension programs should prioritize the issues to be resolved

1.2.2 rehabilitate lands and agricultural resources

\subsection{3 credits with no interest but profit sharing}

1.2.4 government should protect the farmers from unfair market, e.g. to purchase products from farmers with good prices

1.2.5 rural extension services under coordinating related stakeholders

1.3.1 the business sector conduct social responsibility in rural areas

1.3.2 engage agents in the service for sustainable agriculture

1.3.3 co-operate for better seed supply and marketing the products

1.4.1 intergrating the program with outreach activities in rural areas

1.4.2 need agreement between local government with universities to develop program regularly to facilitate organization development, social innovation, and appropriate technology

2.1 adjust the program (SDGs related aspects) that inline with the goals to be attained

2.2 focus on those who interest, and try to consolidate the schedule and develop program that contribute better impact for people

2.3 link the services with interests or concerns of private sectors

2.4.1 integrate monitoring and evaluation into implementation

2.4.2 budget allocation for evaluation

3.1 local government and private companies need to train on this issue and support facilities

3.2 increase purchasing power to providing jobs and poverty alleviation

3.3 price controls and market operations, the household in rural and urban may plant chilli in home yard for consumption

4.1 facilitation the community to work together in managing the outputs/quality products/services

4.2 the government asisst community leaders and village head to find strategy to ensure the dialog forum exists to strengthen relations and co-operation 
term (1-2 years), the five components of rural extension services need to be stressed to develop its potentials, face the challenges, and do transformative changes to improve performa of rural extension systems. The five components are: (i) farmers and rural community system, including market for inputs and outputs, (ii) knowledge management system, (iii) innovation \& information system, (iv) extension services providers, and (v) support facilities for co-learning \& actions. An umbrella for this initiative is the Law Number 16/2006 about Agricultural, Fisheries, and Forestry Extension Systems and the Law Number 23/2014 about Local Government. Furthermore, the commitment of the government to eliminate poverty, food sovereignity, provide employment, and partnership are the basis for intended changes in rural extension. Monitoring and evaluation should be integrating in planning for rural extension services. Capacity development for agent of changes (extension workers, farmer leader, cadre, women farmers, facilitator, social worker, and voluenteer) should be programmed to address rural people needs. Center for information in the village level can play a role as learning and sharing centre for farmers and wider community in rural areas.

In the medium term (2-5 years), capital and human assets are two compolsory aspects to invest to strengthen rural extension system. Government and private sectors are two main stakeholders to support this actions. Capital in terms of financial support should be allocated not only to reach rural people living in remote areas that find limited access to information from digital aparatus, but also to facilitate rural people across the country. The important of investing in capital (financial and human assets) has also suggested by Kerua and Glyde (2016) in their research article about supporting cocoa farmers in livelihood activities in Papua Nugini. Maintenance rural infrastructure should be programmed not only for agriculture, but also for non agriculture purposes. Farmers needs for local financial institution can be facilitated in village in the forms of cooperative or other according the needs. As well as public services such as education and health services, market for agricultural inputs, food, and other goods for daily life should be easily found in the village. Regular face to face meetings for multistakeholders of rural extension system need to be held to coordinate and consolidation service.

In the long terms ( $>5$ to 30 years), the government, organization and private company engaged in extension systems has to develop strategic planning and actions for future extension service with consideration to long term issues based on current situation. For example: the availability of food to feed 9 million people in 2050, the face of agriculture in the next 25 years, advancement of information and computer technology to assist collective learning in community, effect of climate change to agriculture, fisheries, forestry and livestock, and interest of people in rural issues. Situation in the future is ultimately depended on managing current rural issues.

\section{Conclusion}

Rural extension systems in Indonesia face a phase of transition due to changing policy, structure, organization, and the rural situation changes. Farmers and related stakeholders of rural development confirm that rural extension services are urgently needed to facilitate on-farm and off farm agricultural issues. The services should be integrated in a system to facilitate intended better changes. In terms of SDGs several issues should be resolved including poverty, more employment, availability of inputs and infrastructure, education and training, and food \& nutrition. Strengthened rural extension systems can be done through transforming internal and external system for better services, concrete actions to manage inputs, facilitate process, handling products and services from rural people, and better manage the benefits for rural community.

\section{Acknowledgement}

The authors thank Ministry of Research, Technology and Higher Education of the Republic of Indonesia for the support to the study, colleagues in extension agency, extension staff, farmers, women farmers and informants that have participated in discussions.

\section{References}

Amanah,S.2007.MaknaPenyuluhandanTransformasi Perilaku Manusia (Understanding Extension and Human Behaviour Transformation). Jurnal Penyuluhan (Extension Journal). 3(1): 63-67.

Amanah, S. 2008. Peran Strategis Penyuluhan Pembangunan: Tinjauan dari Sisi Akademis (The Strategic Role of Extension-Education: Review 
from Scientific Approach), Makalah dalam Sarasehan Nasional Penyuluhan Pembangunan, 70 tahun Prof Dr Pang S Asngari (Paper Presented in National Meeting 70 years Prof Dr Pang S Asngari, Februari 23 2008).

Amanah, S. 2013. Metode Penyuluhan Pertanian dan Pedesaan (Agriculture and Rural Extension Methods), Paper presented at Academic Workshop of Communication and Community Development Department, 17 August 2013 FEMA IPB.

Bawden, R. 2005. Systemic Development at Hawkesbury: Some Personal Lessons from Experience. Systems Research and Behavioral Science. 22 (2): 151-164.

Central Bureau of Statistics (Badan Pusat Statistik). 2013. Laporan Bulanan Data Sosial Ekonomi September 2013 (Monthly Socio-Economics Report September 2013). Jakarta (ID): Central Bureau of Statistics (Badan Pusat Statistik) Indonesia.

Central Bureau of Statistics (Badan Pusat Statistik). 2017. Laporan Bulanan Data Sosial Ekonomi Maret 2017 (Monthly Socio-Economics Report March 2017). Jakarta (ID): Central Bureau of Statistics (Badan Pusat Statistik) Indonesia.

Davis, K. 2016. How Will Extension Contribute to the Sustainable Development Goals? A Global Strategy and Operational Plan, Commentary Article. Journal of International Agricultural and Extension Education. 23(1).

Gabathuler, E, Bachmann, F \& Kläy A (eds). 2011. Reshaping Rural Extension. Learning for Sustainability (LforS) - an Integrative and Learning-based Advisory Approach for rural Extension with Small-Scale Farmers. Margraf, Weikersheim, Germany \& Technical Centre for Agricultural and Rural Cooperation ACP-EU (CTA). Netherlands: Wageningen.

Garforth, C \& Lawrence, A. 1997. Supporting Sustainable Agriculture through Extension in Asia. Natural Resource Perspective ODI, Number 21.

Herianto, AS, Wastutinigsih SP, Foster D, Rimmer M, \& Callinan R. 2010. Agricultural and fisheries extension in Indonesia: origins, transitions and current challenges. Extension Farming Systems Journal. 6 (1), AFBMNetwork Available from: http://www.csu.edu.au/faculty/science/saws/ afbmnetwork/efsjournal/index.htm 23.
Hermanto \& Hardono, GS. 2015. Dinamika PDB Sektor Pertanian dan Pendapatan Petani. Panel Petani Nasional: Rekonstruksi Agenda Peningkatan Kesejahteraan. Eds: Irawan B, Ariningsih E, Pasandaran E, Indonesian Agency for Agricultural Research and Development (IAARD). Available from: pse.litbang.pertanian. go.id/ ind/pdffiles/patanas.

Kerua, W \& Glyde, S. 2016. Beyond the Cocoa Farm: A New Look at Farmers' Choices in Livelihood Activities and Impact on Productivity in Selected Areas of Papua New Guinea, Rural Extension \& Innovation Systems Journal. 12(1): 1-11. Available from: http://www.apen.org.au/reis-vol12-no-1.

Kolopaking, LM, Amanah, S, Tjitropranoto, P, Anggraeni, L, Syaf, S. .2012. Studi Kualitatif Efek Rembesan Pilot PNPM Lingkungan Mandiri Perdesaan di Indonesia Program Nasional Pemberdayaan Masyarakat Mandiri Perdesaan (Qualitative Study on Spillover Effects of Community Empowerment National Program: Environmental Rural Autonomy) in Indonesia, Center for Agricultural and Rural Development Studies (CARDS). Bogor (ID): Bogor Agricultural University (IPB).

Leagan, PJ. 1962. Extension Education for Community Development in Extension Education for Community Development. New Delhi: Directorate of Extension Ministry of Food and Agriculture, Government of India.

Leeuwis, C. 2004. Communication for Rural Innovation. Rethinking Agricultural Extension. Oxford: Blackwell Publishing,

Ministry of Agriculture. 2016. Data on Agricultural Extension Services, Extension Body and Agriculture Human Resources Development. Jakarta (ID): Kementerian Pertanian RI (Ministry of Agriculture Republic of Indonesia).

Ministry of Domestic Affairs .2016. Kode dan Data Wilayah Administrasi Pemerintahan Per Provinsi, Kabupaten/Kota Dan Kecamatan Seluruh Indonesia, Kementerian Dalam Negeri RI (Ministry of Home Affair Republic of Indonesia. Jakarta (ID): Available from http://www. kemendagri.go.id/media/documents/2015/02/25/ 1/a/lampiran_i.pdf [240317]

Ministry of Environment and Forestry .2016. Jumlah Penyuluh Kehutanan (Number of Forestry Extension Workers), Data on Environment and Forestry. Available from: ttps://drive.google.com/ 
file/d/0B3iBo8knJdOiczU0Q1NPV2dvdHc/ view.

Ministry of Fisheries and Marine Affairs .2016. Jumlah Penyuluh Perikanan, Pusat Penyuluhan Perikanan - Kelautan (Center for Fishery Extension). Jakarta (ID): Kementerian Perikanan \& Kelautan RI (Ministry of Fisheries \& Marine Affairs Republic of Indonesia).

Powell, ET. 2001. Logic Model: A Program Performance Framework, Program Development and Evaluation, Madison Workshop, University of Wisconsin - Extension-Cooperative Extension, December 5, 2001. Madison.

Pretty J. 1995. Regenerating Agriculture Policies and Practice for Sustainability and Self-Reliance. Washington: Joseph Henry Press.

Rhoades, RE \& Booth, RH. 1982. Farmer-back-tofarmer: A Model for Generating Acceptable Agricultural Technology. Lima: Working Paper 1982-1, Social Science Department, International Potato Center Aptd 05969.

Rivera, WM \& Qamar, MK. 2003. Extension, Rural Development and the Food Security Challenge. Rome: Food and Agriculture Organization of the United Nations.

Shepherd, AW. 2007. Approaches to linking producers to markets, A review of experiences to date Agricultural Management, Marketing and Finance Service, FAO Rural Infrastructure and Agro-Industries Division, Occassional Paper 13. Rome: Food and Agriculture Organization of the United Nations.

Slamet, M .2003. Pola Perilaku Manusia Pembangunan, in Yustina, I \& Sudrajat, A. Bogor (ID): IPB Press.

Swanson, BE .2006. The Changing Role of Agricultural Extension in a Global Economy, Seminal Article Series, Journal of International Agricultural and Extension Education. 13(3): 5-17. doi: 10.5191/jiaee.2006.13301.

Swanson, BE \& Rajalahti, R .2010. Strengthening Agricultural Extension and Advisory Systems: Procedures for Assessing, Transforming, and Evaluating Extension Systems, Agriculture and Rural Development. Washington DC: The World Bank. 